\title{
ANALISIS 4K KARYAWAN TENAGA PENDIDIK
}

\author{
*Edi Siregar \\ *Dosen Tetap PPS Universitas Satya Negara Indonesia Jl.Arteri Pondok Indah No.11 Jakarta. \\ edisiregarusni@gmail.com
}

\begin{abstract}
ABSTRAK
Penelitian dilakukan untuk menguji dan menganalisis pengaruh kompetensi, komitmen dan kompensasi terhadap kinerja karyawan.Menggunakan metode survey dengan kuesioner sebagai instrumen utamanya.Populasi penelitian ini adalah tenaga pendidikyang berjumlah 89 , dengan metode sensus dimana semua anggota populasi dijadikan sampel.Analisis data dilakukan dengan analisis regresi, penguji hipotesis melalui uji f dan uji t.Hasil analisis ditemukan terdapat hubungan dan pengaruh signifikan baik secara parsial maupun simultan antara kompetensi, komitmen dan kompensasi dengan kinerja karyawan.

Kata Kunci 4K: Kompetensi, Komitemen, Kompensasi; Kinerja Karyawan.

\section{ABSTRACT}

The research was conducted to test and analyze the effect of competence, commitment and compensation on employee performance. This study used a survey method with a questionnaire as the main instrument. The populations of this study were 89 employees, with a census method where all members of the population were sampled. Data analysis was performed using regression analysis, hypothesis testing through $f$ test and $t$ test. The results of the analysis found that there is a significant relationship and influence both partially and simultaneously between competence, commitment and compensation with employee performance.

Keywords: Competence, Commitment, Compensation; Employee Performance.
\end{abstract}

\section{PENDAHULUAN}

Sumber Daya Manusia (SDM) adalah faktor sentral dalam suatu organisasi, apapun bentuk serta tujuannya, organisasi dibuat berdasarkan visi, misi, dan tujuan untuk kepentingan manusia.Manusia merupakan faktor strategis dalam semua kegiatan institusi atau organisasi maupun profit maupun non profit.

Kinerja karyawan menjadi masalah tersendiri dalam setiap institusi atau organisasi.Kinerja karayawan adalah hasil kerja yang dapat dicapai baik individu maupun kelompok dalam suatu institusi atau organisasi.Fenomena hasil kerja yang dimaksud tentu sesuai dengan wewenang dan tanggung jawab yang diberikan institusi atau organisasi kepada setiap karyawan dalam mencapai visi, misi dan tujuan institusi atau organisasi dengan kemampuan menyelesaikan masalah sesuai dengan waktu yang ditentukan dan tidak melanggar hukum.

Kompetensi adalah kemampuan individu karyawan untuk melaksanakan suatu pekerjaan dengan benar dan memiliki keunggulan yang didasarkan pada hal-hal yang menyangkut pengetahuan (knowledge), keahlian (skill), dan sikap (attitude). Kompetensi adalah kemampuan yang dibawa oleh seorang tenaga kerja ke dalam suatu lapangan pekerjaan dalam bentuk jenis dan tingkatan perilaku yang berbeda. Masalah kompetensi disini mencakup motif, sifat, konsep diri, pengetahuan, dan keterampilan karyawanyang menentukan kinerja karyawan.

Komitmen seseorang terhadap organisasi, perusahaan dan atau institusi pendidikan seringkali menjadi isu yang sangat penting.Komitmen menjadi fenomena tersendiri dalam dunia usaha maupun dunia industri agar tercipta kondisi dan iklim kerja yang kondusif.Dengan komitmen kerja karyawan diharapkan organisasi, perusahaan dan atau institusi pendidikan dapat berjalan secara efisien dan efektif.Masalah komitmen pekerja umumnya dipengaruhi dengan 
iklim kerja yangkurang menunjang, fasilitas yang kurang, hubungan kerja kurang harmonis, jaminan sosial dan keamanan kurang, dan lain sebagainya.

Kompensasi merupakan sumber penghasilan bagi karyawan dan keluarganya, selain itu pemberian kompensasi juga berdampak terhadap kondisi psikologis bagi guru sebagai tenaga pendidik.Masalah kompensasi salah satunya yaitu kompensasi non finansial yaitu kompensasi dalam bentuk non uang yang meliputi kesempatan bagi guru sebagai tenaga pendidik untuk mendapatkan promosi peningkatan karier, pengembangan diri, dan atau penghargaan lainnya.Oleh karena itu perlu dilakukan analisis terhadap variabel 4K,yaitu:Kompetensi, Komitmen, Kompensasi dan Kinerja karyawan berkaitan dengan pengaruh diantara variabel 4K tersebut.

\section{LANDASAN TEORI}

\section{A. Kinerja Karyawan}

Kinerja karyawan dari kata performance yang berarti hasil kerja seseorang pekerja, dimana hasil kerja tersebut harus dapat ditunjukkan buktinya secara konkrit dan dapat diukur.Dengan kinerja akan diketahui kemampuan karyawan dalam melaksanakan tugas yang diberikan.Menurut Busro (2018:89) kinerja karyawan adalah hasil kerja yang dapat dicapai pegawai baik individu maupun kelompok dalam suatu organisasi, sesuai dengan wewenang dan tanggung jawab yang diberikan organisasi dalam mencapai visi dan misi serta tujuan organisasi dengan kemampuan menyelesaikan masalah sesuai dengan waktu yang ditentukan dan tidak melanggar hukum.Menurut Hadari dalam Maulana (2015), kinerja karyawan adalah hasil dari pelaksanaan suatu pekerjaan, baik yang bersifat fisik/mental maupun non fisik/non mental.

Menurut Rivai dan Basri dalam buku Lijan Sinambela (2017:478) mengatakan kinerja karyawan merupakan salah satu faktor keberhasilan penentuan pencapaian tugas terhadap individu yang dapat mengarahkan pada penetapan kinerja organisasi.

Berdasarkan beberapa pendapat diatas dapat disintesiskan bahwa kinerja karyawan adalah prosesberorientasi yang dicapai oleh karyawan sesuai perannya dalam organisasi sesuai dengan standar yang telah ditentukan untuk memaksimalkan produktivitas. Kinerja karyawan adalah hasil kerja yang dilakukan oleh seseorang dalam suatu organisasi atau institusi untukmencapai tujuan yang diharapkan meminimalisir kerugian.

\section{Dimensi dan Indikator Kinerja Karyawan}

a. Hasil kerja:Objek berwujud atau tak berwujud, dengan indikator, yaitu:

1) Kualitas hasil kerja: Kualitas merupakan suatu tuntutan bagi perusahaan agar perusahaan dapat bertahan hidup dalam berbagai bentuk persaingan.

2) Kuantitas hasil kerja:Menggambarkanpemenuhan target yang telah ditetapkan sehingga menunjukkan kemampuan organisasi dalam mengelola sumber daya yang dimiliki untuk mencapai tujuan.

3) Efisiensi dalam melaksanakan tugas:Menggambarkan waktu kerja melaksanakan tugas yang dianggap paling efisien dan efektif pada semua tingkatan manajemen.

b.Pelaku kerja:Tindakan dan sikap yang ditunjukan oleh pekerja, dengan indikator, yaitu:

1) Disiplin kerja: Menggambarkan tingkat ketepatan waktu dan tingkat kehadiran.

2) Inisiatif: Menunjukkan seberapa besar kemampuan karyawan untuk menganalisis, menilai, menciptakan dan membuat keputusan terhadap penyelesaian masalah yang dihadapinya.

3) Ketelitian: Kesesuaian diantara beberapa data pengukuran yang sama yang dilakukan secara berulang.

c. Sifat pribadi:Keadaan atas sifat masing-masing diri, dengan indikator, yaitu:

1) Kejujuran: Ketulusan hati karyawan dalam melaksanakan dan kemampuan untuk tidak menyalahgunakan wewenang yang diembannya.

2) Kreativitas:Kemampuan untuk mengajukan ide-ide/usulan-usulan baru yang konstruktif demi kelancaran pekerjaan, mengurangi biaya, memperbaiki hasil kerja dan menambah 
produktivitas,Busro (2018:99-100).

\section{B. Kompetensi}

Secara umum, pengertian kompetensi merupakan suatu kemampuan atau kecakapan yang dipunyai oleh seseorang di dalam melaksanakan suatu pekerjaan atau tugas pada bidang tertentu, sesuai dengan jabatan yang disandangnya.Menurut Mitrani dalam Muhammad Busro (2018:25) kompetensi adalah bagian yang mendalam dan melekat kepada seseorang serta perilaku yang dapat diprediksi pada berbagai keadaan dan tugas pekerjaan.

Menurut Edison,dkk. (2016) kompetensi adalah kemampuan individu untuk melaksanakan suatu pekerjaan dengan benar dan memiliki keunggulan yang didasarkan pada halhal yang menyangkut pengetahuan (knowledge), keahlian (skill), dan sikap (attitude).

Berdasarkan pendapat diatas, maka dapat dikatakan bahwa kompetensi adalah pengetahuan, keterampilan, sikap dan kemampuan yang dimilikiseorang karyawan sehingga dapat mengerjakan atau melakukan tugas yang diberikan kepadanya.

\section{Dimensi dan Indikator Kompetensi}

a. Pengetahuan (knowledge):Kesadaran dalam bidang kognitif dengan indikator:

1) Identifikasi belajar

2) Cara pembelajaran yang baik sesuai dengan kebutuhan yang ada di perusahaan.

b. Pemahaman (understanding):Kedalaman kognitif dan afektif yang dimiliki oleh individu, dengan indikator:

1) Pemahaman yang baik tentang karakteristik, dan

2) Kondisi kerja secara efektif dan efisien.

c. Nilai (value):Suatu perilaku yang telah diyakini dan secara psikologis telah menyatukan dalam diri seseorang, dengan indikator:

1) Kejujuran,

2) Keterbukaan,

3) Demokratis.

d. Kemampuan (skill):Sesuatu yang dimiliki oleh individu untuk melaksanakan tugas atau pekerjaan yang dibebankan kepada karyawan, dengan indikator:

1) Metode kerja yang dianggap lebih efektif, dan

2) Efisien.

e. Sikap (attitude):Perasaan (senang tidak senang, suka tidak suka) atau reaksi terhadap suatu rangsangan yang datang dari luar, dengan indikator:

1) Reaksi terhadap krisis ekonomi, dan

2) Perasaan terhadap kenaikan gaji.

f. Minat (interest):Kecenderungan untuk melakukan suatu perbuatan, dengan indikator:

1) Aktivitas kerja, dan

2) Semangat kerja,Busro (2018, hal 35).

\section{Komitmen}

Menurut Mathis dan Jckson (2011) dalam Busro (2018:71) komitmen organisasi merupakan tingkat kepercayaan dan penerimaan tenaga kerja terhadap tujuan organisasi dan mempunyai keinginan untuk tetap ada didalam organisasi tersebut.Ketika karyawan tidak mempunyai komitmen terhadap organisasi, maka mereka akan bekerja secara acuh tak acuh, dan tidak akan mampu menghasilkan kinerja yang tinggi yang pada akhirnya mereka akan meninggalkan organisasi, baik karena kesadaran sendiri maupun diberhentikan oleh perusahaan, Suryaman: 2016) dalam Busro (2018:71).

Menurut Street dalam Yuwalliatin (2006) dalam Busro (2018:71) mendefinisikan komitmen organisasi sebagai rasa identitas, keterlibatan, dan loyalitas yang dinyatakan oleh seseorang karyawan terhadap organisasi. 
Dari pendapat-pendapat di atas dapat disintesiskan bahwa komitmen adalah keadaan psikologis individu yang berhubungan dengan keyakinan, kepercayaan, penerimaan yang kuat terhadap tujuan dan nilai-nilai organisasi, kemauan yang kuat untuk bekerja demi organisasi sertakeinginantetapmenjadi anggota organisasi.

\section{Dimensi dan Indikator Komitmen}

Dimensi dan indikator komitmen dalam Busro (2018: 86) menyatakan bahwa komponen atau dimensi mempunyai indikator komitmen sebagai berikut:

a. Komitmen afektif (Affective Commitment): Berkaitan dengan adanya keinginan untuk terikat pada organisasi atau keterikatan emosional karyawan. Identifikasi dan keterlibatan dalam organisasi terjadi apabila karyawan ingin menjadi bagian dari organisasi karena adanya ikatan emosional atau merasa mempunyai nilai sama dengan indikator:

1) Kepercayaan yang kuat dan menerima nilai dan tujuan organisasi.

2) Loyalitas terhadap organisasi, yaitu adanya keinginan yang kuat untuk menjaga keanggotaan di dalam organisasi.

3) Kerelaan menggunakan upaya demi kepentingan organisasi.

b. Komitmen berkelanjutan (Continue Commitment): Suatu kesadaran akan biaya-biaya yang harus dikeluarkan atau ditanggung (kerugian baik finansial maupun kerugian lain) berhubungan dengan keluarnya karyawan dari organisasi dengan indikator:

1) Memperhitungkan keuntungan untuk tetap bekerja dalam organisasi.

2) Memperhitungkan kerugian jika meninggalkan organisasi.

c. Komitmen normatif (Normative Commitment): Perasaan wajib karyawan untuk tetap tinggal dalam suatu organisasi karena adanya perasaan utang budi pada organisasidengan indikator:

1) Kemauan bekerja,

2) Tanggung jawab memajukan organisasi.

\section{Kompensasi}

Menurut Hasibuan (2017:119) kompensasi adalah semua pendapatan yang berbentuk uang, barang langsung atau tidak langsung yang diterima karyawan sebagai imbalan atas jasa yang diberikan kepada perusahaan. Menururt Wibowo (2016:271) kompensasi adalah jumlah paket yang ditawarkan organisasi kepada pekerja sebagai imbalan atas penggunaan tenaga kerjanya. Menurut Marwansyah (2016:269) kompensasi adalah penghargaan atau imbalan langsung maupun tidak langsung, finansial maupun non finansial, yang adil dan layak kepada karyawan, sebagai balasan atau kontribusi/jasanya terhadap pencapaian tujuan perusahaan.

Berdasarkan pendapat di atas dapat disintesiskan bahwa, kompensasi adalah segala sesuatu yang diterima karyawan sebagai balas jasa untuk kerja mereka baik secara langsung maupun tidak langsung, finansial maupun non finansial, yang adil dan layak bagi karyawan terhadap pencapaian tujuan perusahaan.

\section{Dimensi dan Indikator Kompensasi Non Finansaial}

Menurut Simamora (dalam Recha, Bambang dan Yunialdi 2016) Dimensi kompensasi non finansial dapat dilihat dari pekerjaan dan lingkungan kerja, yaitu:

a. Pekerjaan:Pemberian tugas-tugas yang menarik sesuai dengan peraturan perusahaan sehingga mencapai prestasi kerja, dengan indikator yaitu:

1) Tugas yang bervariasi: Dapat membuat karyawan lebih mengasah kemampuannya.

2) Jam kerja sesuai Undang-Undang: Jam kerja tidak melebihi batas yang sudah diatur oleh pemerintah di dalam undang-undang ketenagakerjaan No. 13 tahun 2003.

3) Kesempatan untuk berkembang: Setiap karyawan memiliki kesempatan untuk mengembangkan potensi di dalam diri masing-masing agar dapat bekerja secara maksimal. 
4) Penghargaan atas prestasi karyawan: Penghargaan atas prestasi yang sudah dilakukan oleh karyawan adalah cara yang efektif untuk meningkatkan semangat karyawan dalam bekerja.

b. Lingkungan kerja:Bila karyawan merasa nyaman dengan lingkungan kerja mereka maka karyawan akan bersemangat dalam bekerja, dengan indikator yaitu:

1) Kebijakan yang sesuai: Kebijakan perusahaan harus fleksibel, mudah diinterpretasikan dan dimengerti oleh semua karyawan agar perusahaan tidak kesulitan untuk pengambilan keputusan.

2) Supervisor yang berkompeten: Supervisor haruslah menjadi seorang yang kompeten di bidangnya karena kelak karyawan akan merasa bangga apabila memiliki supervisor yang kompeten.

3) Lingkungan kerja yang nyaman: Lingkungan kerja di dalam perusahaan sangat penting bagi karyawan karena apabila karyawan merasa nyaman dengan lingkungan kerja mereka maka karyawan akan bersemangat dalam bekerja.

4) Kerabat kerja yang menyenangkan: Karyawan yang memiliki kerabat atau rekan kerja yang selalu menjalin komunikasi yang terbuka dalam hal pekerjaan atau hal yang bersifat pribadi dapat membuat karyawan tidak merasa terancam di lingkungan kerja mereka.

\section{METODE PENELITIAN}

\section{A. Tempat dan Waktu Penelitian}

Tempat penelitian di Perguruan Islam Al Izhar Pondok Labu, yang beralamat di Jalan Rumah Sakit Fatmawati Kav.49 RT. 007 / RW.001, Kelurahan Pondok Labu, Kecamatan Cilandak, Kota Jakarta Selatan, Daerah Khusus Ibukota Jakarta 12450.Waktu penelitian dilakukan mulai bulan Maret 2020 sampai dengan Mei 2020.

\section{B. Populasi dan Sampel}

Menurut Soewadji (2012: 129) populasi merupakan objek penelitian.Populasi adalah sekelompok unsur atau elemen yang dapat berbentuk manusia atau individu, binatang, tumbuhtumbuhan, lembaga atau institusi, kelompok, dokumen, kejadian sesuatu hal, gejala, atau berbentuk konsep yang menjadi objek penelitian.Populasi penelitian ini adalah 89 orang karyawan guru sebagai tenaga pendidik.

Menurut Syofian Siregar (2014: 56)sampel adalah prosedur pengambilan data.Peneliti menggunakan teknik sampling sensus.Hal ini sering dilakukan bila jumlah populasi relatif kecil.Berdasarkan jumlah populasi dan teknik sampling yang digunakan, maka jumlah sampel dalam penelitian ini berjumlah 89 responden.

\section{Metode Analisis Data}

\section{Tabel}

Descriptive Statistics

\begin{tabular}{|l|c|c|c|c|c|}
\hline & $\mathrm{N}$ & Minimum & Maximum & Mean & Std. Deviation \\
\hline Kinerja Karyawan & 89 & 65 & 103 & 89.9888 & 9.16700 \\
Kompetensi & 89 & 115 & 179 & 152.6854 & 13.66448 \\
Komitmen & 89 & 61 & 96 & 80.4719 & 8.98242 \\
Kompensasi Non & 89 & 56 & 89 & 72.5506 & 6.36398 \\
finansial & 89 & & & & \\
Valid N (listwise) & & & & \\
\hline
\end{tabular}


a. Hasil Deskriptif Variabel Kinerja Karyawan (Y)

Nilai minimum atau nilai terendah untuk jawaban pernyataan kuesioner pada variabel kinerja karyawan (Y) sebesar 65. Nilai maximum atau nilai tertinggi untuk variabel kinerja karyawan (Y) sebesar 103, dengan nilai mean atau nilai rata-rata sebesar 89,989. Nilai Standar deviasi adalah ukuran penyebaran data dari rata-rata variabel kinerja karyawan (Y) sebesar 9,167. b. Hasil Deskriptif Variabel Kompetensi $\left(\mathrm{X}_{1}\right)$

Nilai minimum atau nilai terendah untuk jawaban pernyataan kuesioner pada variabel kompetensi $\left(\mathrm{X}_{1}\right)$ sebesar 115. Nilai maximum atau nilai tertinggi untuk kompetensi $\left(\mathrm{X}_{1}\right)$ sebesar 179 dengan nilai mean atau nilai rata-rata variabel kompetensi $\left(\mathrm{X}_{1}\right)$ sebesar 152,685 sedangkan standar deviasi sebesar 13,664.

c. Hasil Deskriptif Variabel Komitmen $\left(\mathrm{X}_{2}\right)$

Nilai minimum atau nilai terendah untuk jawaban pernyataan kuesioner pada variabel komitmen $\left(\mathrm{X}_{2}\right)$ sebesar 61 . Nilai maximum atau nilai tertinggi untuk variabel komitmen $\left(\mathrm{X}_{2}\right)$ sebesar 96, dengan nilai mean atau nilai rata-ratanya sebesar 80,471.Standar deviasi variabel komitmen $\left(\mathrm{X}_{2}\right)$ nilainya sebesar 8,982.

d. Hasil Deskriptif Variabel Kompetensi Non Finansial $\left(\mathrm{X}_{3}\right)$

Nilai minimum atau nilai terendah untuk jawaban pertanyaan kuesioner pada variabel kompetensi non finansial $\left(\mathrm{X}_{3}\right)$ sebesar 56. Nilai maximum atau nilai tertinggi untuk variabel kompetensi non finansial $\left(\mathrm{X}_{3}\right)$ sebesar 89 , dengan nilai mean atau nilai rata-ratanya sebesar 72,550. Standar deviasi pada variabel kompensasi non finansial $\left(\mathrm{X}_{3}\right)$ sebesar 6,364.

\section{Uji Autokorelasi}

Uji autokorelasi bertujuan untuk menguji apakah dalam model regresi linear ada korelasi antara kesalahan pengganggu pada periode $t$ dengan kesalahan pengganggu pada periode $t-1$ (sebelumnya). Autokorelasi muncul karena observasi yang berurutan sepanjang waktu berkaitan satu sama lain. Hal ini sering ditemukan pada data runtut waktu (time series), karena sampel atau observasi tertentu cenderung dipengaruhi oleh observasi sebelumnya. Untuk mendeteksi ada tidaknya autokorelasi dengan cara melakukan uji Durbin-Watson (DW test), (Ghozali,2018). Pengambilan keputusan pada uji Durbin Watson (DW test) sebagai berikut:

a. DU $<$ DW $<4$ - DU, maka Ho diterima, artinya tidak terjadi autokorelasi.

b. DW $<$ DL atau DW $>4$ - DL, maka Ho ditolak, artinya terjadi autokorelasi.

c. $\mathrm{DL}<\mathrm{DW}<$ atau $4-\mathrm{DL}$, artinya tidak ada kepastian atau kesimpulan yang pasti.

\section{Tabel}

\section{Output Uji Autokorelasi} Model Summary ${ }^{b}$

\begin{tabular}{|l|r|r|r|r|r|}
\hline Model & $\mathrm{R}$ & R Square & $\begin{array}{c}\text { Adjusted R } \\
\text { Square }\end{array}$ & $\begin{array}{c}\text { Std. Error of the } \\
\text { Estimate }\end{array}$ & Durbin-Watson \\
\hline 1 & $.358^{\mathrm{a}}$ & .128 & .098 & 8.70856 & 2.154 \\
\hline
\end{tabular}

a. Predictors: (Constant), Kompensasi, Kompetensi, Komitmen

b. Dependent Variable: Kinerja Karyawan

Berdasarkan tabel output "Model Summary" di atas, diketahui nilai Durbin-Watson (d) adalah sebesar 2.154. Selanjutnya nilai tersebut dibandingkan dengan nilai tabel Durbin-Watson (d) pada signifikan 5\% dengan rumus $(\mathrm{k} ; \mathrm{N})$. Adapun jumlah variabel idenpenden adalah 3 atau $\mathrm{k}=3$, sementara jumlah sampel atau $\mathrm{N}=89$, maka (3;89). Hasil angka tersebut dapat dilihat pada distribusi nilai tabel Durbin Waston (d) dengan nilai dL sebesar 1.589 dan dU sebesar 1.725. Sehingga dapat diketahui nilai Durbin-Waston (d) sebesar 2.154 lebih besar dari batas atas degree upper $(\mathrm{dU})$ yakni 1.725 , dan kurang dari (4-dU) $4-1.725=2.275$, maka tidak terdapat masalah atau gejala autokorelasi. Setelah melalui proses olah data, diperoleh output hasil perhitungan statistik Durbin-Waston (d) sebagai berikut:

$$
\mathrm{dL}=1.589
$$




$$
\begin{gathered}
\mathrm{dU}=1.727 \\
4-\mathrm{dU}=4-1.727=2.275
\end{gathered}
$$

\section{F. Analisis Regresi Linier Berganda}

Menurut Ghozali (2018), analisis regresi linear berganda digunakan untuk mengetahui arah dan seberapa besar pengaruh variabel independen terhadap variabel dependen. Hasil dari analisis regresi linear berganda akan menguji seberapa besar pengaruh Kompetensi $\left(\mathrm{X}_{1}\right)$, Komitmen $\left(\mathrm{X}_{2}\right)$, dan Kompensasi $\left(\mathrm{X}_{3}\right)$ Terhadap Kinerja Karyawan $(\mathrm{Y})$, dengan perhitungan persamaanya adalah sebagai berikut:

$$
\mathrm{Y}=\mathrm{a}+\mathrm{b}_{1} \mathrm{X}_{1}+\mathrm{b}_{2} \mathrm{X}_{2}+\mathrm{b}_{3} \mathrm{X}_{3}+\mathrm{e}
$$

\begin{tabular}{|c|c|c|c|c|c|}
\hline \multirow[b]{2}{*}{ Model } & \multicolumn{2}{|c|}{$\begin{array}{c}\text { Unstandardized } \\
\text { Coefficients }\end{array}$} & \multirow{2}{*}{$\begin{array}{c}\begin{array}{c}\text { Standardized } \\
\text { Coefficients }\end{array} \\
\text { Beta }\end{array}$} & \multirow[b]{2}{*}{$\mathrm{t}$} & \multirow[b]{2}{*}{ Sig. } \\
\hline & B & Std. Error & & & \\
\hline 1 (Constant) & 42.955 & 12.268 & & 3.501 & .001 \\
\hline Kompetensi & .053 & .045 & -.089 & -1.178 & .242 \\
\hline Komitmen & .618 & .067 & .706 & 9.239 & .000 \\
\hline $\begin{array}{l}\text { Kompensasi Non } \\
\text { Finansial }\end{array}$ & .023 & .094 & -.018 & -.249 & .804 \\
\hline
\end{tabular}

Tabel

Coefficients $^{\mathrm{a}}$

a. Dependent Variable: Kinerja Karyawan

Berdasarkan hasil uji regresi linier berganda pada tabel di atas dapat dihitung persamaan dengan rumus:

$$
\begin{aligned}
& Y=a+b_{1} X_{1}+b_{2} X_{2}+b_{3} X_{3}+e \\
& Y=42.955+0.053 X_{1}+0.618 X_{2}+0.023 X_{3}
\end{aligned}
$$

\section{G. Uji Hipotesis}

\section{Uji f}

Uji f digunakan untuk menguji apakah terdapat pengaruh signifikan antara variabel independen secara bersama-sama terhadap variabel dependen dengan kelayakan model yang dihasilkan dengan menggunakan uji kelayakan model pada tingkat $\alpha$ sebesar 0,05 . Jika nilai signifikansi uji $\mathrm{F}<0,05$ maka model yang digunakan dalam penelitian layak dan dapat dipergunakan untuk analisis berikutnya, begitupun sebaliknya (Ghozali, 2018:179).

a. $\quad$ Jika sig $\mathrm{f}<$ pada sig $\alpha 0.05$, maka Ho ditolak.

b. Jika $f_{\text {hitung }}>\mathrm{f}_{\text {tabel }}$ pada $\alpha 0.05$, maka $\mathrm{H}_{1}$ diterima.

Berdasarkan signifikansi:

a. Jika signifikansi $<0.05$ maka, Ho diterima.

b. Jika signifikansi $>0.05$ maka, Ho ditolak.

Menentukan $\mathrm{f}$ tabel pada tingkat signifikansi 0.05 dengan df 1 (jumlah variabel-1) atau 4$1=3$, dan df2 (n-k-1) atau 89-4 = 85, maka hasil $\mathrm{f}$ table $=2,71$.

Tabel

ANOVA $^{\mathrm{a}}$

\begin{tabular}{|ll|r|r|r|r|r|}
\hline Model & & Sum of Squares & Df & Mean Square & F & Sig. \\
\hline 1 & Regression & 3123.588 & 3 & 1041.196 & 33.521 & $.000^{\mathrm{b}}$ \\
& Residual & 2640.188 & 85 & 31.061 & & \\
& Total & 5763.775 & 88 & & & \\
\hline
\end{tabular}

a. Dependent Variable: Kinerja Karyawan

b. Predictors: (Constant), Kompensasi, Kompetensi, Komitmen 
Pada tabel di atas hasil uji $\mathrm{f}$ atau Anova menunjukkan hasil $\mathrm{f}_{\text {hitung }}$ sebesar 33.521 dengan $\mathrm{f}$ tabel sebesar 2.71, maka nilai $\mathrm{f}_{\text {hitung }}>\mathrm{f}_{\text {tabel }}(33.521>2,71)$ dan nilai probabilitas diterima (signifikan). Karena nilai signifikasi $0,000<0.05$, maka diterima (signifikan).Dengan ini didapati bahwa variabel Kompetensi $\left(\mathrm{X}_{1}\right)$, Komitmen $\left(\mathrm{X}_{2}\right)$, dan Kompensasi $\left(\mathrm{X}_{3}\right)$,secara simultan berpengaruh positif terhadap kinerja karyawan $(\mathrm{Y})$, dengan demikian $\mathrm{H}_{\mathrm{a} 1}$ diterima dan $\mathrm{H}_{01}$ diterima.

\section{Uji t (Uji Parsial)}

Uji t pada dasarnya menunjukkan seberapa jauh pengaruh variabel independen secara individual terhadap variabel dependen. Cara melakukan uji t dengan tingkat signifikansi $(a)=$ 0,05 adalah dengan membandingkan nilai t hitungnya dengan $t$ tabel yaitu:

a. Jika thitung $>\mathrm{t}$ tabel maka, Ho ditolak

b. Jika t hitung $<\mathrm{t}$ tabel maka, Ho diterima

Berdasarkan signifikansi:

1) Jika signifikan $>0,05$ maka Ho diterima.

2) Jika signifikan $<0,05$ maka Ho ditolak.

Uji statistik $\mathrm{t}$ atau uji parsial digunakan untuk mengetahui apakah model regresi variabel kompetensi, komitmen dan kompensasi non finansial secara parsial berpengaruh signifikan terhadap variabel dependen yaitu kinerja karyawan, jika kolom sig $<$ dari probabilitas 0,05 dan $\mathrm{t}_{\text {hitung }}>\mathrm{t}_{\text {tabel }}$ maka Ho ditolak dan Ha diterima. Nilai $\mathrm{t}$ tabel dihitung dari 2-tailed $\alpha: 0,05 / 2=$ $0,025, \mathrm{df}=\mathrm{n}-3=89-3=89$, sehingga diperoleh $\mathbf{t}_{\text {tabel }}=\mathbf{1 , 9 8 7}$.

Berdasrkan nilai signifikan (Sig.):

a. Nilai Sig. $<0.05$ (probabilitas), maka diterima.

b. Nilai Sig. $>0.05$ (probabilitas), maka ditolak.

Berdasarkan nilai thitung dengan ttabel:

a. Nilai $t_{\text {hitung }}>t_{\text {tabel }}$, maka diterima.

b. Nilai $t_{\text {hitung }}<\mathrm{t}_{\text {tabel}}$, maka ditolak.

Tabel

Output Hasil Uji t

Coefficients $^{\mathrm{a}}$

\begin{tabular}{|c|c|c|c|c|c|}
\hline \multirow[b]{2}{*}{ Model } & \multicolumn{2}{|c|}{ Unstandardized Coefficients } & \multirow{2}{*}{$\begin{array}{c}\begin{array}{c}\text { Standardized } \\
\text { Coefficients }\end{array} \\
\text { Beta }\end{array}$} & \multirow[b]{2}{*}{$\mathrm{t}$} & \multirow[b]{2}{*}{ Sig. } \\
\hline & B & Std. Error & & & \\
\hline 1 (Constant) & 50.300 & 17.491 & & 2.876 & .005 \\
\hline Kompetensi & -.067 & .068 & -.101 & -.993 & .324 \\
\hline Komitmen & .269 & .104 & .264 & 2.598 & .011 \\
\hline Kompensasi & .349 & .146 & .242 & 2.383 & .019 \\
\hline
\end{tabular}

a. Dependent Variable: Kinerja Karyawan

Berdasarkan tabelOutput Hasil Uji t menunjukan hasil sebagai berikut:

1. Berdasarkan tabel output SPSS "Coefficients" pada tabel 4.18 diketahui nilai sginifikasi (Sig) variabel kompetensi $\left(\mathrm{X}_{1}\right)$ sebesar $0.324>0.05$ maka dapat disimpulkan bahwa $\mathrm{H}_{1}$ atau hipotesis pertama ditolak, artinya tidak ada pengaruh kompetensi $\left(\mathrm{X}_{1}\right)$ terhadap variabel kinerja karyawan $(\mathrm{Y})$. Sedangkan berdasarkan nilai $\mathrm{t}_{\text {hitung }}$ variabel kompetensi $\left(\mathrm{X}_{1}\right)$ sebesar 0.993, karena nilai thitung 0.993 lebih kecil dari t tabel $1.987(0.993<1.987)$, maka ditolak artinya tidak ada pengaruh kompetensi $\left(\mathrm{X}_{1}\right)$ terhadap kinerja karyawan $(\mathrm{Y})$.

2. Variabel komitmen $\left(\mathrm{X}_{2}\right)$ sebesar $0.11>0.05$ maka dapat disimpulkan bahwa $\mathrm{H}_{2}$ atau hipotesis kedua ditolak, artinya tidak ada pengaruh kompetensi $\left(\mathrm{X}_{2}\right)$ terhadap variabel kinerja karyawan 
(Y). Sedangkan berdarakan nilai $t_{\text {hitung }}$ variabel komitmen $\left(\mathrm{X}_{2}\right)$ sebesar 2.598, karena nilai $\mathrm{t}_{\text {hitung }}$ 2.598 lebih besar dari t tabel 1.987 (2.598 >1.987), maka diterima, artinya ada pengaruh komitmen $\left(\mathrm{X}_{2}\right)$ terhadap kinerja karaywan $(\mathrm{Y})$.

3. Pada tabel di atas diketahui nilai sginifikasi (Sig) variabel kompetensi $\left(\mathrm{X}_{3}\right)$ sebesar $0.19>0.05$ maka dapat dikatakan bahwa $\mathrm{H}_{3}$ atau hipotesis pertama ditolak, artinya tidak ada pengaruh kompensasi $\left(\mathrm{X}_{3}\right)$ terhadap variabel kinerja karyawan $(\mathrm{Y})$. Sedangkan berdarakan nilai t hitung variabel kompensasi $\left(\mathrm{X}_{3}\right)$ sebesar 2.383, karena nilai t hitung 2.383 lebih besar dari t tabel $1.987(2.383>1.987)$, maka artinya ada pengaruh kompensasi $\left(\mathrm{X}_{3}\right)$ terhadap kinerja karyawan (Y).

\section{H. Uji Koefisien Determinasi $\left(\mathbf{R}^{2}\right)$}

Koefisien determinasi menunjukan seberapa besar kemampuan variabel independent (Kompetensi, Komitmen dan Kompensasi) dalam menjelaskan variance variabel dependent, yaitu Kinerja Karyawan. Dari hasil analisis regresi hasilnya dapat disajikan sebagai berikut:

Tabel

Hasil Uji Koefisien Determinasi $\left(\mathbf{R}^{2}\right)$ Model Summary ${ }^{b}$

\begin{tabular}{|l|c|c|c|c|}
\hline Model & $\mathrm{R}$ & R Square & $\begin{array}{c}\text { Adjusted R } \\
\text { Square }\end{array}$ & $\begin{array}{c}\text { Std. Error of the } \\
\text { Estimate }\end{array}$ \\
\hline 1 & $.736^{\mathrm{a}}$ & .542 & .526 & 5.57324 \\
\hline
\end{tabular}

a. Predictors: (Constant), Kompensasi, Kompetensi, Komitmen

b. Dependent Variable: Kinerja Karyawan

Koefisien determinasi dalam regresi linier berganda digunakan untuk mengetahui presentase sumbangan pengaruh variabel independen $\left(\mathrm{X}_{1}, \mathrm{X}_{2}, \mathrm{X}_{3}\right)$ secara bersama terhadap variabel dependent $(\mathrm{Y})$.Adjusted $R$ Square $=0$, artinya variabel independentsama sekali tidak terdapat pengaruh terhadap variabel dependent. Jika Adjusted $R$ Square semakin mendekati 1, yang berarti mendekati $100 \%$, artinya variabel independent berpengaruh terhadap dependent.Dari tabel 4.19 dapat dilihat bahwa nilai Adjusted $R$ Square adalah 0.526.AdjustedRSquare disebut juga dengan koefisien determinasi sehingga dalam hal ini berarti 52.6\% menunjukkan bahwa persentase sumbangan pengaruh variabel independent(Kompetensi, Komitmen, dan Kompensasi) terhadap variabel dependent (Kinerja Karyawan). Sedangkan sisanya sebesar 52.6\% (100\% $47.4 \%=52.6 \%$ ) dipengaruhi atau dijelaskan oleh variabel lain yang tidak diteliti dalam penelitian.

\section{PENUTUP}

\section{A. Kesimpulan}

Dari hasil penelitian Analisis 4K Karyawan Tenaga Pendidikmengenai pengaruh Kompetensi, Komitmen, dan Kompensasi terhadap Kinerja Karyawan pada Perguruan Islam A1 Izhar Pondok Labudapat disimpulkan sebagai berikut:

1. Kompetensi $\left(\mathrm{X}_{1}\right)$ berpengaruh signifikan terhadap kinerja karyawan $(\mathrm{Y})$. Dengan demikian $\mathrm{H}_{01}$ diterima dan $\mathrm{H}_{\mathrm{a} 1}$ diterima, yang artinya secara parsial variabel kompetensi berpengaruh signifikan terhadap variabel kinerja karyawan.

2. Komitmen $\left(\mathrm{X}_{2}\right)$ tidak berpengaruh signifikan terhadap kinerja karyawan $(\mathrm{Y})$, artinya secara parsial variabel komitmen tidak berpengaruh signifikan terhadap variabel kinerja karyawan.

3. Kompensasi $\left(\mathrm{X}_{3}\right)$ tidak berpengaruh signifikan terhadap kinerja karyawan $(\mathrm{Y})$ dengan demikian $\mathrm{H}_{03}$ ditolak dan $\mathrm{H}_{\mathrm{a} 3}$ diterima, artinya secara parsial variabel komitmen berpengaruh signifikan terhadap variabel kinerja karyawan. 
4. Kompetensi $\left(\mathrm{X}_{1}\right)$, komitmen $\left(\mathrm{X}_{2}\right)$, dan kompensasi $\left(\mathrm{X}_{3}\right)$, secara simultan berpengaruh positif terhadap kinerja karyawan (Y). Dapat disimpulkan bahwa variabel kompetensi $\left(\mathrm{X}_{1}\right)$, Komitmen $\left(\mathrm{X}_{2}\right)$, dan kompensasi $\left(\mathrm{X}_{3}\right)$,secara bersamaan berpengaruh positif terhadap kinerja karyawan (Y) dengan demikian $\mathrm{H}_{\mathrm{a} 1}$ diterima dan $\mathrm{H}_{01}$ ditolak.

\section{B. Saran}

Berdasarkan hasil pembahasan di atas mengenai pengaruh Kompetensi, Komitmen, dan Kompensasi terhadap Kinerja Karyawan pada Perguruan Islam Al Izhar Pondok Labu, peneliti memberikan saran sebagai bahan masukan dan pertimbangan sebagai berikut:

1. Berdasarakan indikator dan skor terendah pada variabel kinerja karyawan yaitu kualitas kerja karyawan, maka disarankan kepada pihak manajemen sumber daya manusia(SDM) tenaga pendidik yang ada perlu meningkatkan kualitas kerja dengan melakukan pelatihan dan pengembangan SDM dengan memperhatikan keseimbangan karyawan laki-laki dan perempuan.

2. Skor terendah pada variabel kompetensi yaitu pemahaman yang baik tentang karakteristik, maka disarankan sebaiknya pihak pengelola Perguruan Islam Al Izhar Pondok Labu harus berupayameningkatkan tanggung jawab SDM untuk saling bekerja sama dan sama bekerja dalam mencapai visi, misi dan tujuan lembaga sehingga dapat memahami sifat pribadi atau karateristik antara karyawan atau rekan kerja satu dengan yang lainnya.

3. Berdasarkan indikator dengan skor terendah pada variabel komitmen yaitu loyalitas terhadap organisasi, maka disarankan sebaiknya para karyawan tenaga pendidik Perguruan Islam Al Izhar Pondok Labu lebih meningkatkan hasil pekerjaan dalam organisasi dibanding urusan pribadi, dengan membangun tim kerja dan lebih meningkatkan hubungan professional dalam bekerja.

4. Berdasarkan indikator dengan skor terendah pada variabel kompensasi yaitu dalam jam kerja sesuai dengan undang-undang, maka disarankan kepada Yayasan selaku Pembina Perguruan Islam Al Izhar Pondok Labu harus berupaya mengatur lebih tegas terhadap jam kerja karyawan dalam kontrak kerja yang sesuai dengan Undang-Undang dalam Pedoman Umum Hubungan Kerja, sehingga karyawan dapat bekerja lebih bertanggung jawab dan menerima kompensasi kerja yang baik menambah semangat kerja karyawan tenaga pendidik.

5. Bagi para karyawan dan peneliti selanjutnya atau berikutnya disarankan membahas variabel lainterutama yang berhubungan dengan Kompetensi, Komitmen, Kompensasi dan Kinerja dengan kajian dari sudut pandang yang berbeda.

\section{DAFTAR PUSTAKA}

\section{$\underline{\text { Buku }}$}

Afipuddien,\& Sugiyono. (2016). Pengaruh Dukungan Organisasi, Komitmen Afektif dan Perilaku Ekstra Peran terhadap Kinerja Karyawan PT. Nur Medinah Intermedia.

Busro, Dr. Muhammad. (2018). Teori-Teori Manajemen Sumber Daya Manusia, Prenada Media. Dessler, Gary. 2016. Manajemen Sumber Daya Manusia. Jakarta: Salemba Empat.

Pengembangan Kinerja Guru Melalui: Kompetensi, Komitmen dan Motivasi Kerja/Dr. Abd. Madjid, M. Ag/Yogyakarta: Samudra Biru, 2016.

Sugiyono. 2018. Metode Penelitian Kuantitatif, Kualitatif, dan R\&D. Bandung: Alfabeta.

\section{Jurnal}


Andi, dan Eci Novita. 2016. "Pengaruh Kompetensi, Motivasi, Dan Kepuasan Kerja Terhadap Produktivitas Karyawan Pada PT. Perindustrian Dan Perdagangan Bangkinang”. Procuratio Vol. 04, No. 02, 18.

Ali Zaenal Abidin, 2019 Model Kinerja Perawat Puskesmas Provinsi Banten Universitas Pendidikan Indonesia.

Budiman, Novelisa P, Ivonne S Saerang, dan Greis M Sendow. 2016. "Pengaruh Kompetensi, Motivasi, Dan Disiplin Kerja Terhadap Kinerja Karyawan (Studi Pada PT. Hasjrat Abadi Tendean Manado) The Effectof Competence, Motivation, And Work Discipline On Employee Performance (Study On PT. Hasjrat Abadi Tendean Manado)”. Jurnal EMBA Vol.4 No.4, Hal. 321-332.

Grace Fredriksz Pengaruh Kompensasi Finansial dan Kompensasi Nonfinansial terhadap Kinerja Karyawan (Prgram Studi Administrasi Bisnis, Politeknik Negeri Ambon Jl. Ir. M. Putuhena Wailela Rumahtiga Ambon, 97234, Maluku), Vol. 2 No. 2 (2017) hlm.143-152.

Reni Oktavianti, Soedjarwo, \& Ismet Basuki, Analisis Pengaruh Pemberian Kompensasi Non Finansial Terhadap Komitmen Dan Kinerja Guru Pascasarjana Manajemen Pendidikan, Universitas Negeri Surabaya, Surabaya, Indonesia, Vol. 33 No. 1 April 2019.

Wibowo, Manajemen Kinerja edisi ke 5, (Jakarta : Rajawali Pers, 2016), hlm 27240 Ignatius Jeffrey, Ruliyanto. "The Effect of Competence, Training and Work Discipline towards Employees' Performance (A Case Study at PT. Krakatau Argo Logistics)".International Journal of Business and Management Invention.Vol.6 No. 7. Jakarta. 2017.

Yohanes Susanto1, Sukoco2 Magister Manajemen Universitas Bina Insan Lubulinggau1,2Yohanessusanto@Univbinainsan.Ac.Id1,Sukoco@Gmail.Com2 Pengaruh Kompetensi, Komitmen Kerja Dan Motivasi Kerja Terhadap Kinerja Pegawai Di Dinas Kependudukan Dan Pencatatan Sipil Kota Lubuklinggau, Vol. 24, No 